ESJ Social Sciences

\title{
Domestic violence against children and adolescents in Taif, Saudi Arabia: Analytical study from the school counsellor's perspective
}

\author{
Ahmed Al Hariri, \\ (Professor of Mental Health), Taif University/Department of Psychology, Saudi Arabia \\ Eman Faisal, \\ (Assistant Professor in Research Design and Methodology) \\ Department of Curriculum and Instruction, Saudi Arabia \\ Rasha Al Harthi, \\ (MA in Psychology), Taif University/Department of Psychology, Saudi Arabia \\ Fozeah Al Harthi, \\ (MA in Psychology), Taif University/Department of Psychology, Saudi Arabia \\ Amal Hamed Al Harthi, \\ (MA in Psychology), Taif University/Department of Psychology, Saudi Arabia
}

Doi:10.19044/esj.2021.v17n8p68

Submitted: 05 March 2021

Accepted: 19 March 2021

Published: 31 March 2021
Copyright 2021 Author(s)

Under Creative Commons BY-NC-ND

4.0 OPEN ACCES

Cite As:

Al Hariri, A., Faisal, E., Al Harthi, R., Al Harthi, F. and Al Harthi, AH. (2021). Domestic violence against children and adolescents in Taif, Saudi Arabia: Analytical study from the school counsellor's perspective. European Scientific Journal, ESJ, 17(8), 68. https://doi.org/10.19044/esj.2021.v17n8p68

\begin{abstract}
The study aimed to recognise the differences, relationships, and prediction of domestic violence among school students from the school counsellors in Taif, Saudi Arabia. A mixed-methods approach was used in collecting and analysing quantitative and qualitative data. A questionnaire and interviews were used. The sample that answered the questionnaire included 84 schools' counsellors, whereas the sample that answered the interviews was 13 schools' counsellors. Results showed that there are significant differences at $p<.05$ in the domestic violence suffered by students: students in primary school $(\mathrm{M}=3.83 ; \mathrm{SD}=.910)$, and in particular the students who study in schools with between 1001 and 1200 students $(\mathrm{M}=2.301 ; \mathrm{SD}=.311)$ and who study in schools with between 801 and $1000(\mathrm{M}=2.299, \mathrm{SD}=.419)$, but there was no difference regarding the experience of schools' counsellors. There were positive correlations at $p<.05$ between domestic violence and
\end{abstract}


both the total number of students in a school $($ rho $=.14)$ and the experience of schools' counsellors (rho $=.09$ ) but not with the stage of education. It is also impossible to predict domestic violence incidents by using the total number of students in a school, schools' counsellors' experience, and the stage of education. Qualitative data from the interviews were used to support the findings of the quantitative data. For example, school counsellors from secondary school stressed that they dealt with students who suffer from domestic violence, and from crowded schools agreed that they saw many students who suffer from domestic violence. The results of this article showed the importance of investigating domestic violence in underresearched societies, such as school students from Saudi Arabia. This study ended with some recommendations. One recommendation is to have enough schools' counsellors based on the total number of students in a school. Other recommendations that enhance mental health in schools and increase the quality of a schools' counsellor's work.

Key Words: Domestic Violence; School Students; Schools' Counsellors

\section{Introduction:}

This study aimed to explore the school students who suffer from violence using information about their school level, school counsellor experience, and the total number of students in their schools - from the school counsellors' perspective. This research is essential because it adds to the literature in the related areas such as school students who suffer from domestic violence and the influence of the school counsellors' experience on exploring these students and dealing with them. It is essential also because it discusses such issues in the under-researched population - Saudi school students.

The National Survey of Mental Health's technical report in Saudi Arabia (2019) indicated that the prevalence of mental disorders among Saudi youth is $40 \%$ at $15-24$ years. In other words, two out of five people at this particular age suffer from mental issues. This prevalence is higher than in Australia, and Europe combined but lower than in the United States. ElGilany and Amr (2010) discussed mental problems and disorders among children and adolescents in Middle Eastern countries such as 35\% of school students in Egypt suffer from anxiety, 37.4\% of Iraqi children have psychiatric disorders, more than $13 \%$ of elementary school students in the UAE have some form of behavioural disorders. The report of the national survey also showed the percentage of many disorders such as, but not limited to, separation anxiety (11.9\%), ADHD (8\%), depression (6\%), social phobia (5.6\%), and obsessive-compulsive disorder (4.1\%), all of which were 
investigated among youths aged $15-18$ years old, i.e., students in secondary school. Such mental issues and behavioural problems may directly affect the violence and neglect that this age group is exposed to.

Al Hariri (2017) found that $43 \%$ of intermediate school students at Taif show signs of behavioural disorders and problems, e.g., assaulting teachers $(32 \%)$, assaulting others $(50 \%)$, provoking teachers $(51 \%)$, provoking family members at home $(40 \%)$, having problems with family members $(36 \%)$, and living in a tense home environment (34\%). Another study conducted by $\mathrm{Al}$ Hariri (2016) found that the students in their last year of intermediate school in Taif showed a higher average number of social problems.

The Guidance and Counseling Department in Taif Education - by AlQarni, Al-Thamali, and Al-Fifi (2019) - conducted a survey study on a sample of 17,271 students in 59 elementary, 33 intermediate, and 28 secondary schools. The results showed 92 cases of family disintegration and 36 cases of family neglect - both in the elementary stage.

All these studies stressed the issues of violence or neglect reflected in the students' behaviour and eventually led to social and academic problems. Based on the research team's experience in psychology and education, one of the best resources to use to gain a better understanding of students who suffer from violence or neglect is the school counsellor as they seek and receive information about students' behaviour from multiple stakeholders (Nassar-Mcmillan, Karvonen, Perez, and Abrams, 2009). Therefore, the current study aimed to investigate students who suffer from violence from the school counsellor's perspective.

\section{Research questions:}

1. What are the differences in students who suffer from violence based on their school level, school counsellor experience, and the total number of students in a school?

2. What are the relationships between exploring students who suffer from violence and their school level, school counsellor experience, and the total number of students in a school?

\section{Research aims:}

This study aimed:

1. To investigate the differences in students who suffer from violence based on their school level, school counsellor experience, and the total number of students in a school.

2. To identify the relationships between exploring students who suffer from violence and their school level, school counsellor experience, and the total number of students in a school. 
The current research community are Saudi school counsellors at elementary, intermediate and secondary schools for boys in Taif.

\section{Methodology:}

\section{Research design:}

This mixed-methods research used an explanatory two-sequential stage design. This methodology allows for comprehensive quantitative data and indepth qualitative data to be used, i.e., it increases the quality of research (Johnson \& Onwuegbuzie, 2004; Lund, 2012). There is a lack of mixed methodology research in developing countries (Teddlie \& Tashakkori, 2010), such as Saudi Arabia. Therefore, this study will contribute to filling this gap in the body of research.

The two stages were: quantitative data phase to answer the research questions, and then qualitative data phase to explain the quantitative results. Both data types were collected from school counsellors.

\section{Research samples:}

\section{The sample of the questionnaire:}

The population is the Saudi school counsellors. The questionnaire was administrated on a simple, randomly selected sample of school counsellors by using a barcode reader (n. 25894, on 28/02/2019) provided by Taif Education Administration. Forty-eight counsellors completed the questionnaire (representing approximately $20 \%$ of the population). Table 1 shows the demographic information of the participants who completed the questionnaire.

\section{The sample of the interviews:}

Thirteen school counsellors voluntarily participated to be interviewed. They worked across all three school levels in different schools (ranging from schools with a small number of students to overcrowded schools), and all have different experiences. It is worth highlighting that conducting 12 interviews in scientific research is sufficient to reach qualitative data saturation (Guest, Bunce \& Johnson, 2006, p.74). This means that the researcher reaches a stage of collecting qualitative information where no new classifications or topics appear with him/her after that (DiCicco-Bloom \& Crabtree, 2006, pp. 317-318).

This supports the adequacy and method of selecting the interview sample in the current research, and the characteristics of the sample that were interviewed are shown in Table 1. 
Table 1: Demographic information about the participants in the two samples

\begin{tabular}{|c|c|c|c|c|c|}
\hline \multicolumn{3}{|c|}{$\begin{array}{l}\text { Participants of the Quantitative Stage }(n= \\
\text { 84) }\end{array}$} & \multicolumn{3}{|c|}{$\begin{array}{l}\text { Participants of the Qualitative Stage }(n= \\
13)\end{array}$} \\
\hline Variable & Group & $\%$ & Variable & Group & $\mathbf{n}$ \\
\hline \multirow[t]{4}{*}{ SL } & Primary & 32.14 & \multirow[t]{3}{*}{$\mathrm{SL}$} & Primary & 3 \\
\hline & Intermediate & 34.5 & & Intermediate & 6 \\
\hline & \multirow[t]{2}{*}{ Secondary } & 33.33 & & Secondary & 4 \\
\hline & & $100 \%$ & & \multirow{2}{*}{$\begin{array}{r}\text { Total } \\
\text { From } 1 \text { to } 200\end{array}$} & 13 \\
\hline \multirow[t]{7}{*}{ TNSS } & From 1 to 200 & 16.6 & \multirow[t]{6}{*}{ TNSS } & & - \\
\hline & From 201 to 400 & 13.1 & & From 201 to 400 & 2 \\
\hline & From 401 to 600 & 19 & & From 401 to 600 & 6 \\
\hline & From 601 to 800 & 14.3 & & From 601 to 800 & 3 \\
\hline & From 801 to 1000 & 15.5 & & From 801 to 1000 & - \\
\hline & \multirow[t]{2}{*}{ From 1001 to 1200} & 21.4 & & From 1001 to 1200 & 2 \\
\hline & & $100 \%$ & & Total & 13 \\
\hline \multirow[t]{7}{*}{ SCE } & Less than two years & 13 & \multirow[t]{6}{*}{ SCE } & Less than two years & 3 \\
\hline & $\begin{array}{c}\text { From } 2 \text { to less than four } \\
\text { years }\end{array}$ & 16.7 & & $\begin{array}{c}\text { From } 2 \text { to less than four } \\
\text { years }\end{array}$ & - \\
\hline & $\begin{array}{c}\text { From } 4 \text { to less than six } \\
\text { years }\end{array}$ & 13 & & $\begin{array}{c}\text { From } 4 \text { to less than six } \\
\text { years }\end{array}$ & 3 \\
\hline & $\begin{array}{c}\text { From } 6 \text { to less than eight } \\
\text { years }\end{array}$ & 14.3 & & $\begin{array}{c}\text { From } 6 \text { to less than eight } \\
\text { years }\end{array}$ & - \\
\hline & $\begin{array}{c}\text { From } 8 \text { to less than ten } \\
\text { years }\end{array}$ & 14.5 & & $\begin{array}{c}\text { From } 8 \text { to less than ten } \\
\text { years }\end{array}$ & 1 \\
\hline & Ten years and more & 27.4 & & Ten years and more & 6 \\
\hline & & $100 \%$ & & Total & 13 \\
\hline
\end{tabular}

\section{Research instruments:}

\section{Structured questionnaire:}

The research team built a structured questionnaire describing domestic violence's essential features as stated in the World Health Organization's ICD-10, the DSM-IV \& DSM-5 of the American Psychiatric Association (APA), and some related literature and studies, such as Radford, 2013; Valiulis, 2014. This resulted in nine items that describe the violence that students may suffer from.

It is worth noting that De Vaus (2010) emphasized the impossibility of determining the number of a questionnaire's items or the length of a scale, especially in the field of social sciences. This length depends on several factors, e.g., the target community, the nature of the questions and phrases in terms of their simplicity or complexity, and the topic's importance to the target group. Based on their experience in the educational research field, the current research team believes that nine phrases are sufficient that can express domestic violence suffered by students across three school levels. 
There are, however, questionnaires with less than nine items, such as the Generalised Anxiety Disorder, which has seven AB ARAT (Bártolo, Monteiro, \& Pereira, 2017).

\section{a) Questionnaire's validity:}

Internal consistency was conducted using Spearman's Correlation Coefficients between each item and the questionnaire's total score, as shown in Table 2.

Table 2: Item correlations in the questionnaire of domestic violence questionnaire

\begin{tabular}{|c|c|c|c|}
\hline & $\begin{array}{l}\text { Items } \\
\text { To what extent do you deal with }\end{array}$ & $\begin{array}{c}\text { Correlation } \\
\text { with the } \\
\text { scale }^{*} \\
\end{array}$ & P-value \\
\hline 1 & cases of students with a family rift & .451 & $<.001$ \\
\hline 2 & cases of family disintegration & .419 & $<.001$ \\
\hline 3 & cases of domestic violence & .616 & $<.001$ \\
\hline 4 & $\begin{array}{l}\text { cases of students neglected by their families in } \\
\text { general }\end{array}$ & .732 & $<.001$ \\
\hline 5 & $\begin{array}{l}\text { cases showing a rise in students neglected by } \\
\text { their families }\end{array}$ & .762 & $<.001$ \\
\hline 6 & $\begin{array}{l}\text { students who have been neglecting their } \\
\text { education due to their families }\end{array}$ & .818 & $<.001$ \\
\hline 7 & $\begin{array}{c}\text { students whose health is neglected by their } \\
\text { families }\end{array}$ & .712 & $<.001$ \\
\hline 8 & $\begin{array}{l}\text { cases of the religiously neglected students from } \\
\text { their families }\end{array}$ & .603 & $<.001$ \\
\hline 9 & $\begin{array}{l}\text { students whose nutrition is neglected by their } \\
\text { families }\end{array}$ & .591 & $<.001$ \\
\hline
\end{tabular}

The questionnaire's internal validity was significant at $\mathrm{p}<.001$, and all the correlations were above .30. This means that the questionnaire is valid and its results are trustworthy.

\section{b) Questionnaire's reliability}

Cronbach's Alpha Coefficient $(\alpha)$ was used to check the questionnaire's reliability. The $\alpha$ of the whole questionnaire was .793, i.e., the questionnaire is reliable.

\section{Semi-structured interviews}

A semi-structured interview was conducted on thirteen school counsellors. These interviews aimed to understand the students who suffer from domestic violence from their school counsellor's perspective. This type of interview directs the participants to talk about a specific topic whilst leaving space for them to freely express their feelings and thoughts within the particular question's framework (Morgan, 1997; Robson, 2011; Bryman, 2012). 


\section{Data Analysis:}

Quantitative data was entered to SPSS (version 24) and it was coded as: strongly agree $=5$, agree $=4$, neutral $=3$, disagree $=2$, strongly disagree $=1$. Kolmogorov-Smirnov showed that the data was not normally distributed, which is the norm in social sciences research. One-way analysis of variance - ANOVA was used to investigate the differences in the domestic violence suffered by students according to the school level, the number of students in the school, and the school counsellors' experience. Spearman's Rank-Order Correlation coefficient was adopted to identify the relationships between exploring the students who suffer from violence and their school level, school counsellor experience, and the total number of students in a school.

Qualitative data was analyzed by using thematic analysis. It is an approach to organising and describing the data in more depth and detail (Braun \& Clark, 2006: 79). This type of analysis also helps explain the studied issue (Anderson \& Kanuka, 2003; DiCicco-Bloom \& Crabtree, 2006).

\section{Results and discussion:}

Q1. To investigate the differences in the students who suffer from violence based on their school level, school counsellor experience, and the total number of students in a school.

One-way analysis of variance - ANOVA was used to answer the first question, as shown in Table 3.

Table 3: ANOVA shows the significant differences in domestic violence $(n=84)$

\begin{tabular}{|c|c|c|c|c|c|c|c|}
\hline & Variable & $\begin{array}{l}\text { Sum of } \\
\text { Squares }\end{array}$ & df & $\begin{array}{c}\text { Mean } \\
\text { Square }\end{array}$ & $\mathbf{F}$ & Sig.* & $\eta^{2}$ \\
\hline \multirow{3}{*}{ SL } & $\begin{array}{c}\text { Between } \\
\text { Groups }\end{array}$ & 198.069 & 2 & 99.034 & \multirow{3}{*}{4.651} & \multirow{3}{*}{$.02 *$} & \multirow{3}{*}{.023} \\
\hline & $\begin{array}{l}\text { Within } \\
\text { Groups }\end{array}$ & 8556.944 & 81 & 105.641 & & & \\
\hline & Total & 8755.004 & 83 & & & & \\
\hline \multirow{3}{*}{ TNSS } & $\begin{array}{c}\text { Between } \\
\text { Groups }\end{array}$ & 291.112 & 5 & 43.822 & \multirow{3}{*}{5.511} & \multirow{3}{*}{$.03 *$} & \multirow{3}{*}{.028} \\
\hline & $\begin{array}{l}\text { Within } \\
\text { Groups }\end{array}$ & 9912.016 & 78 & 127.077 & & & \\
\hline & Total & 10131.128 & 83 & & & & \\
\hline \multirow{3}{*}{ SCE } & $\begin{array}{c}\text { Between } \\
\text { Groups }\end{array}$ & 378.968 & 5 & 40.793 & \multirow{3}{*}{1.939} & \multirow{3}{*}{.09} & \multirow{3}{*}{-} \\
\hline & $\begin{array}{l}\text { Within } \\
\text { Groups }\end{array}$ & 9471.971 & 78 & 121.435 & & & \\
\hline & Total & 9675.939 & \multicolumn{2}{|l|}{83} & & & \\
\hline \multicolumn{8}{|c|}{$\begin{array}{r}\mathrm{F}=\text { One-way a } \\
\eta^{2}=\mathrm{Et}\end{array}$} \\
\hline
\end{tabular}




\section{$\mathrm{SL}=$ School Level \\ TNSS $=$ Total Number of Students in a School \\ $\mathrm{SCE}=$ School Counsellors' Experience}

Table 3 illustrates significant differences in students' domestic violence on two variables: school level and students' total number in a school. The effect size for both variables was small $\eta^{2}=.023$ and .028 , respectively. Pallant (2013) discussed that .01 is a small effect size, .06 is a medium effect size, and .14 is a large effect size. Table 4 specifies where these differences are exactly.

Table 4: Tukey HSD shows multiple comparisons $(n=84)$

\begin{tabular}{|c|c|c|c|c|c|c|c|c|c|c|c|}
\hline Variable & & Groups & $\mathbf{n}$ & $\mathbf{M}$ & SD & 1 & 2 & 3 & & & \\
\hline \multirow[t]{4}{*}{ ES } & 1 & Primary & 27 & 3.12 & .906 & - & & & & & \\
\hline & 2 & Intermediate & 29 & 3.86 & .677 & .74 & - & & & & \\
\hline & 3 & Secondary & 28 & 4.63 & .848 & $1.51^{*}$ & .77 & - & & & \\
\hline & & & & & & 1 & 2 & 3 & 4 & 5 & 6 \\
\hline \multirow[t]{6}{*}{ TNSS } & 1 & From 1 to 200 & 14 & 1.37 & .201 & - & & & & & \\
\hline & 2 & From 201 to 400 & 11 & 1.38 & .183 & .01 & - & & & & \\
\hline & 3 & From 401 to 600 & 16 & 1.83 & .161 & .46 & .45 & - & & & \\
\hline & 4 & From 601 to 800 & 12 & 1.86 & .064 & .49 & .48 & .03 & - & & \\
\hline & 5 & From 801 to 1000 & 13 & 1.90 & .212 & .53 & .52 & .07 & .04 & - & \\
\hline & 6 & From 1001 to 1200 & 18 & 2.29 & .335 & $.92 *$ & .91 & .46 & .43 & .39 & - \\
\hline
\end{tabular}

Table 4 shows statistically significant differences at $p<.05$ in domestic violence suffered by students in secondary and elementary schools, in favour of elementary school students $(\mathrm{M}=3.83, \mathrm{SD}=.910)$ with a mean difference $=1.11$. Most of the interviewed counsellors in secondary school stressed that they see cases of students who suffer from domestic violence. This is in line with a number of studies, e.g., Dufva, 2001; Alexander et al., 2005; Rovis et al., 2016; Ralo et al., 2015, that discussed children's suffering at the elementary stage. Annerbäck et al. (2010) confirmed that annually, one child out of 20 at the intermediate level in Sweden suffers from domestic violence, while $14 \%$ of intermediate and secondary school students suffer from violence by a family member (Jernbro and Jansson, 2017).

Besides, there were statistically significant differences at $p<.05$ between schools with fewer than 200 students and crowded schools, in favour of the latter. This difference is specifically true in favour of schools with 1001 to 1200 students $(\mathrm{M}=2.301, \mathrm{SD}=.311)$ with a mean difference equal to 1.056 ; schools with 801 to 1000 students $(\mathrm{M}=2.299$, $\mathrm{SD}=.419)$ with a mean difference equal to 1.054. All the interviewed counsellors who work in crowded schools agreed that many students suffer from domestic violence. In 
consent with this, Jewkes (2002) and Heise (2002) confirm the relationship between domestic violence and crowded places.

The current study did not find a difference in students' domestic violence based on the school counsellors' experience. This is in agreement with Refvem (2000), who confirmed that some counsellors do not have an influential role in dealing with students who suffer from domestic violence. Some of these counsellors need others' help to uncover cases of children suffering from domestic violence.

\section{Q2. To identify the relationships between exploring the students who suffer from violence and their school level, school counsellor experience, and the total number of students in a school.}

Spearman's Rank-Order Correlation was used to show the correlation between domestic violence and the three variables. Pallant (2013) specified three different sizes of correlation: between .10 and .29 is an indicator of small correlation, between .30 and .49 is an indicator of a moderate relationship, and between .50 and 1 is an indicator of a large association.

There was a small positive relationship at $p<.05$ between domestic violence and both the total number of students in the school $($ rho $=.14)$ and the experience of the school counsellors ( $r$ ho $=.09$ ), i.e., the more students in the school, the more likely to find a higher number of students suffering from domestic violence in bigger schools. The greater number of years of experience of a school counsellor, the more likely he/she will recognize cases of those who suffer from domestic violence. Indeed, the interviewed school counsellors in crowded schools and with long experience were the ones who discussed more cases of students suffering from domestic violence. Lloyd (2018) confirmed the link between domestic violence and other variables, including crowded places, e.g., overcrowded schools. The current result is also consistent with Sargin's (2016) findings that school counsellors explain the concept of domestic or family violence as psychological or physical harm to a battered child, which may lead to behavioural problems, mental disorders, bodily injury or death.

However, the current research did not find a relationship between domestic violence and school level (rho $=.007, \mathrm{p}=.18$ ). Maybe this is due to the current division of age groups, i.e. into three stages. Interviewed school counsellors from all three stages discussed domestic violence cases, although the majority of them were in secondary school. Carlos et al. (2017) proved that 227 children aged between one day and 19 years old die due to violence from one of their family members every day around the world. Some studies confirmed the lack of research about domestic and family violence in adolescents (Osofsky, 1999). 
Based on the results of both questions, the research team recommend the following:

Regarding the students in a school:

1. It is essential to have an appropriate number of school counsellors in a school relative to the number of students. This would help maintain the quality of counselling services.

2. It is crucial to reduce the number of students in a school to ensure the quality of student counselling services in line with the best international practices.

3. It is crucial to explore the behavioural problems related to domestic violence that students may suffer from as early as possible across all school levels.

Concerning school counsellors' work:

1. It is essential to benefit from expert school counsellors whose experience exceeds ten years and transfer their knowledge and skills to other counsellors with fewer years of experience.

2. School counsellors must improve their work to design and implement counselling programmes and measure the programme's effectiveness for positive or negatively distinguished cases.

3. It is crucial to continuously educate and qualify the school counsellors about the students' behavioural problems (prevention, diagnosis, and guidance) to increase the effectiveness of counselling services.

4. It is vital to document the outcome of the school counsellor's work and report the cases that he/she dealt with. The aim of this is to show the effectiveness of the school counsellor's job.

5. It is worthwhile assessing the school counsellors' job based on three matters: electronic work, using behavioural measurements, and applying for guidance programmes.

6. It is vital to activate the coordination and cooperative work between mental health hospitals, psychiatric clinics, police stations and counselling services by referring difficult cases and following them up in the school.

7. It is essential to develop a technical/advisory model by the school counsellor and the family members, particularly elementary school students. 


\section{Limitations:}

The current findings are cross-sectional. We cannot confirm causality between the variables. However, this study can be considered as the first step to understand domestic violence among Saudi students, and therefore, this study can direct further research to investigate domestic violence and link it to other factors and investigates mediators and moderators affects. Besides, this study targeted males only, so more comparative studies that include males and females are needed. The study also collected data from school counsellors only, so further research that targeting the students themselves plus their counsellors would be beneficial. However, despite all these limitations, this study adds to the body of literature, especially that it targeted an under-researched population - i.e. Saudi school students.

\section{Conclusion:}

This research aimed to investigate the differences in students who suffer from violence based on their school level, school counsellor experience, and the total number of students in a school. It also aimed to identify the relationships between exploring students who suffer from violence and their school level, school counsellor experience, and the total number of students in a school. A mixed methodology was used. Questionnaire and interview were conducted, and quantitative and qualitative data were used to answer the research questions. We answered the research questions statistically and supported the results with the findings from the qualitative data. The findings confirm the vital role of school counsellors in exploring and dealing with students who suffer from domestic violence. This research can be considered a step in understanding domestic violence that school students suffer in Taif - Saudi Arabia. Further research is needed to compare domestic violence among different groups such as boys and girls or between children and adolescents.

\section{Acknowledgement:}

The authors would like to thank Taif University and its Deanship of Scientific Research. The authors are grateful for the Administration of Education in Taif and all those who volunteered their time to participate in this study.

\section{References:}

Al Hariri, A. (2016). The effects of personal devices and the awareness of their influence and the related factor among a sample of students in intermediate and secondary schools. Journal of Education Faculty / Suez University, 34, 35-57. http://eulc.edu.eg/eulc_v5/libraries/EPublishedJournal.aspx?ScopeID $=1 . \& \mathrm{BibID}=11711684$. 
Al Hariri, A. (2017). Indicators of conduct disorders among adolescents in Saudi Arabia. European Scientific Journal, 13(5), 270-284. https://doi.org/10.19044/esj.2017.v13n5p270.

Alexander, H., Macdonald, E., \& Paton, S. (2005). Raising the issues of domestic abuse in school. Children \& Society, 19(3), 187-198. Retrieved from https://doi.org/10.1002/CHI.837.

Al-Qarni, A., Al-Thamali, A. and Al-Fifi, H. (2019). Survey study about students' cases from their counsellor's perspective in a case study programme, Unpublished study, Guidance administration for students in Taif education administration.

Anderson, T., \& Kanuka, H. (2003). E-research: Methods, strategies and issues. Boston: Pearson Education.

Annerbäck, E.-M., Wingren, G., Svedin, C. G., \& Gustafsson, P. A. (2010). Prevalence and characteristics of child physical abuse in Swedenfindings from a population-based youth survey. Acta Paediatrica, 99(8), 1229-1236. Retrieved from https://doi.org/10.1111/j.16512227.2010.01792x.

Bártolo, A., Monteiro, S., \& Pereira, A. (2017). Factor structure and construct validity of the Generalized Anxiety Disorder 7-item (GAD7) among Portuguese college students. Cadernos De Saúde Pública, 33(9), Cadernos de Saúde Pública, 09/28/2017, Vol.33(9).

Braun, V., \& Clarke, V. (2006). Using thematic analysis in psychology. Qualitative Research in Psychology, 3(2), 77-101. doi:10.1191/1478088706qp063oa.

Bryman, A. (2012). Social research methods (4th ed.). Oxford University Press.

Carlos, D. M., Pádua, E. M. M. D., Fernandes, M. I. D., Leitão, M. N. da C., \& Ferriani, M. das G. C. (2017). Domestic violence against children and adolescents: social support network perspectives. Revista Gaucha de Enfermagem, 37(spe), e72859. Retrieved from https://doiorg.sdl.idm.oclc.org/10.1590/1983-1447.2016.esp.72859.

De Vaus, D. (2012). Research design in social research. SAGE.

DiCicco-Bloom, B., \& Crabtree, B. F. (2006). The qualitative research interview. Medical Education, 40(4), 314-321. https://doi.org/10.1111/j.1365-2929.2006.02418.x.

Dufva, V. (2001). What's troubling the child? Domestic violence as seen by workers in schools. Helsinki: The federation of mother and child homes and shelters.

El-Gilany, A., \& Amr, M. (2010). Child and adolescent mental health in the Middle Eaast: an overview. World Family Medicine Journal, 8(8), 12-18. 
Guest, G., Bunce, A., \& Johnson, L. (2006). How many interviews are enough? An experiment with data saturation and variability. Field Methods, 18(1), 59-82. https://doi.org/10.1177/1525822x05279903.

Hetling, A., \& Zhang, H. (2010). Domestic Violence, Poverty, and Social Services: Does Location Matter? Social Science Quarterly, 91(5), 1144-1163. Retrieved from www.jstor.org/stable/42956454.

Jernbro, C., \& Jansson, S. (2017). Våld mot barn. En nationell kartläggning [Violence against children. A national survey]. Stockholm: Allmänna barnhuset.

Jewkes, R (2002) Intimate partner violence: causes and prevention. Lancet 359: 1423-1429. Retrieved from https:// doi.org/10.1016/S01406736(02)08357-5.

Johnson, B., \& Onwuegbuzie, A. J. (2004). Mixed methods research: A research paradigm whose time has come. Educational Researcher, 33(7), 14-26. http://www.jstor.org/stable/3700093.

Lloyd, M. (2018). Domestic Violence and Education: Examining the Impact of Domestic Violence on Young Children, Children, and Young People and the Potential Role of Schools. Frontiers in psychology, 9, 2094. Retrieved from https://doi.org/10.3389/fpsyg.2018.02094.

Lund, T. (2012). Combining qualitative and quantitative approaches: Some arguments for mixed methods research. Scandinavian Journal of Educational Research, 56(2), 155-165. https://doi.org/10.1080/00313831.2011.568674.

McGuigan, W. M., \& Pratt, C. C. (2001). The predictive impact of domestic violence on three types of child maltreatment. Child Abuse \& Neglect, 25(7), 869-883. Retrieved from https://doiorg.sdl.idm.oclc.org/10.1016/S0145-2134(01)00244-7.

Morgan, D. (1997). Focus groups as qualitative research. 2nd ed. London: SAGE.

Nassar-Mcmillan SC, Karvonen M, Perez TR, Abrams LP. Identity Development and School Climate: The Role of the School Counselor. The Journal of Humanistic Counseling, Education and Development, 48(2), 195-214. The Journal of Humanistic Counseling - Education and Development. 2009;48(2):195-214. doi: 10.1002/j.21611939.2009.tb00078.x.

Osofsky, J. (1999). The impact of violence on children. The Future of Children, 9(3), 33-49. Retrieved from http://www.jstor.com/stable/1602780.

Pallant, J. (2013). SPSS survival manual: A step by step guide to data analysis using SPSS. 5th ed. Maidenhead: Open University Press.

Radford, L. (2013). Domestic Violence. Oxford: University of Oxford Press. 
Ralo, J. M., Schor, N., Tavares, C. M., \& Silva, V. (2015). Prevalence of family violence and associated factors among in-school adolescent in Sao Paulo, Brazil. Journal of interpersonal violence, 31(9), 16181633. Retrieved from https://doi.org/10.1016/j.socscimed.2011.05.006.

Refvem, J. (2000). The Witnesses Walk Your Halls: The School Counselor and Student Victims of Domestic Violence. Eric Digest. (2000). Ed: ED438498.

Retrieved from http://search.ebscohost.com.sdl.idm.oclc.org/login.aspx?direct=true\& $\mathrm{db}=$ eric\&AN=ED438498\&site $=$ ehost-live.

Robson, C. (2011). Real world research (3rd ed.). Wiley.

Rovis, D., Jonkman, H., \& Basic, J. (2016). A multilevel analysis of adverse family relations. School bonding and risk behaviors among adolescents. Journal of Child and Family Studies, 25(2), 647-660. Retrieved from https://doi.org/10.1007/s10826-015-0223-6.

Sargin, N. (2016). Metaphorical Perceptions of "Violence" among Students of Psychological Counselling and Guidance. International Journal of Contemporary Educational Research, 3(2), 47-54.

Teddlie, C., \& Tashakkori, A. (2010). Overview of contemporary issues in mixed methods research. In C. Teddlie \& A. Tashakkori (Eds.), SAGE handbook of mixed methods in social and behavioral research (2nd ed., pp. 1-41). SAGE.

The National Survey of Mental Health in Saudi Arabia. Technical Report King Salman Centre for Disability Research 2019. Available from: https://www.kfshrc.edu.sa/ar/home/news/9697.

Valiulis, C. (2014). Domestic violence. Georgetown Journal of Gender and the Law, 15(1), 123. 